\title{
Equatorial total column of nitrous oxide as measured by IASI on MetOp-A: implications for transport processes
}

\author{
P. Ricaud ${ }^{1}$, J.-L. Attié ${ }^{1,2}$, H. Teyssèdre ${ }^{2}$, L. El Amraoui ${ }^{2}$, V.-H. Peuch ${ }^{2}$, M. Matricardi ${ }^{3}$, and P. Schluessel ${ }^{4}$ \\ ${ }^{1}$ Université de Toulouse, Laboratoire d'Aérologie, CNRS UMR 5560, Toulouse, France \\ ${ }^{2}$ CNRM-GAME, Météo-France and CNRS URA 1357, Toulouse, France \\ ${ }^{3}$ ECMWF, Shinfield Park, Reading, Berkshire, RG2 9AX, UK \\ ${ }^{4}$ Department of Programme Development, EUMETSAT, Am Kavalleriesand 31, 64295 Darmstadt, Germany
}

Received: 31 October 2008 - Published in Atmos. Chem. Phys. Discuss.: 30 January 2009

Revised: 5 May 2009 - Accepted: 2 June 2009 - Published: 17 June 2009

\begin{abstract}
In this paper we use the total columns of nitrous oxide $\left(\mathrm{N}_{2} \mathrm{O}\right)$ as retrieved from the radiance spectra as measured by the Infrared Atmospheric Sounding Interferometer (IASI) instrument aboard the MetOp-A platform and distributed by the European Organisation for the Exploitation of Meteorological Satellites (EUMETSAT) during the MarchMay (MAM) 2008 period. Since the total column of $\mathrm{N}_{2} \mathrm{O}$ reflects concentrations in the middle troposphere, cloud-free columnar $\mathrm{N}_{2} \mathrm{O}$ measurements are used to assess transport processes in the equatorial band $\left(10^{\circ} \mathrm{S}-10^{\circ} \mathrm{N}\right)$. We compare the measured data set with the outputs produced by the 3-D chemical-transport model MOCAGE during the period MAM 2002-2004. To reflect MAM 2008 concentrations, MOCAGE results have been scaled by a factor 1.0125 in order to represent the change in concentration of $\mathrm{N}_{2} \mathrm{O}$ since 2004. IASI $\mathrm{N}_{2} \mathrm{O}$ equatorial measurements show a maximum over Africa $\left(4.96 \times 10^{-3} \mathrm{~kg} \mathrm{~m}^{-2}\right)$ and a minimum over South America $\left(4.86 \times 10^{-3} \mathrm{~kg} \mathrm{~m}^{-2}\right)$ in reasonable agreement with the outputs from MOCAGE despite the fact that emissions of $\mathrm{N}_{2} \mathrm{O}$ are more intense over America than over Africa. The amplitude of the longitudinal variation of total column $\mathrm{N}_{2} \mathrm{O}$ along the equatorial band is twice as intense in the measurements $(\sim 1.6 \%)$ than as in the model calculations $(\sim 0.8 \%)$, and much greater than the IASI mean random error $(0.16-$ $0.33 \%$ ). A difference between the two data sets is observed above the Western Pacific $\left(110^{\circ} \mathrm{E}-150^{\circ} \mathrm{E}\right)$ with a marked minimum in IASI compared to MOCAGE. Recent theoretical studies (Ricaud et al., 2007 and 2009) have shown the potentially important effect of the Walker and the Hadley
\end{abstract}

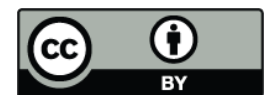

Correspondence to: P. Ricaud (philippe.ricaud@aero.obs-mip.fr) cells on the tropospheric distribution of $\mathrm{N}_{2} \mathrm{O}$ in producing a local maximum in $\mathrm{N}_{2} \mathrm{O}$ above Africa. Based on equatorial total columns of $\mathrm{N}_{2} \mathrm{O}$ retrieved from IASI, our results are consistent with the fact that Africa is a zone of convergence of airmasses coming from different convective regions whilst Western Pacific behaves more like a divergence zone.

\section{Introduction}

Based upon satellite-borne measurements and threedimensional chemical transport models (3-D CTMs), recent studies (Ricaud et al., 2007 and 2009) have shown that longlived species such as nitrous oxide $\left(\mathrm{N}_{2} \mathrm{O}\right)$ can be considered as an excellent tracer to diagnose transport processes in the stratosphere down to the upper troposphere-lower stratosphere within the equatorial band $10^{\circ} \mathrm{S}-10^{\circ} \mathrm{N}$. The annual, semi-annual and quasi-biennial oscillations were analyzed in the stratospheric $\mathrm{N}_{2} \mathrm{O}$ measured and modelled fields and found to be in agreement with results from previous studies. More interestingly, the behaviour of the measured equatorial $\mathrm{N}_{2} \mathrm{O}$ fields in the Tropical Tropopause Layer (TTL) shows longitudinal inhomogeneities with pronounced maxima in May over the African continent and minima over the Western Pacific area up to the 400-K isentropic level, namely in the lower stratosphere. These inhomogenities in the longitudinal distribution of $\mathrm{N}_{2} \mathrm{O}$ were calculated by the Modèle de Chimie Atmosphérique à Grande Echelle (MOCAGE) 3-D CTM in the middle troposphere (340-K isentropic level, $\sim 11 \mathrm{~km}$ ) over the year, and maxima of $\mathrm{N}_{2} \mathrm{O}$ over Africa were attributed to the effect of the permanent Walker and Hadley tropospheric cells. The persistence of the African

Published by Copernicus Publications on behalf of the European Geosciences Union. 
$\mathrm{N}_{2} \mathrm{O}$ maximum in May over Africa in the lower stratosphere was attributed to intense meso-scale convective systems, e.g. overshootings, that can reach the lower stratosphere and that are not included in the MOCAGE CTM, and weak horizontal mixing.

Sources of $\mathrm{N}_{2} \mathrm{O}$ are located primarily in the troposphere (e.g. soils, wetlands, biomass burning, industrial exhausts) except for an auroral source in the upper atmosphere (Semeniuk et al., 2008), and sinks are essentially through photolysis and reaction with electronically-excited oxygen atoms $\mathrm{O}\left({ }^{1} \mathrm{D}\right)$ in the stratosphere (e.g. Brasseur et al., 1999). Nitrous oxide is the major source of nitrogen oxides $\left(\mathrm{NO}_{\mathrm{x}}=\mathrm{NO}+\mathrm{NO}_{2}\right)$ which are important in controlling the distribution of both tropospheric and stratospheric ozone. Its photochemical lifetime can reach about a century in the troposphere. The present study intends to give experimental evidence for the longitudinal inhomogeneity in the tropospheric $\mathrm{N}_{2} \mathrm{O}$ field around the equatorial band $\left(10^{\circ} \mathrm{S}-10^{\circ} \mathrm{N}\right)$ as calculated by MOCAGE.

Tropospheric nitrous oxide is mainly measured by ground-based instruments but also by satellite-borne instruments. Advanced Global Atmospheric Gases Experiment (AGAGE), and its predecessors (the Atmospheric Life Experiment, ALE, and the Global Atmospheric Gases Experiment, GAGE) have been measuring the composition of the global atmosphere continuously since 1978, including surface $\mathrm{N}_{2} \mathrm{O}$ using a highly improved gas chromatograph multidetector system (Prinn et al., 2000). The World Data Centre for Greenhouse Gases (WDCGG) was established under the Global Atmosphere Watch (GAW) programme to collect, archive and provide data for greenhouse $\left(\mathrm{CO}_{2}, \mathrm{CH}_{4}, \mathrm{CFCs}\right.$, $\mathrm{N}_{2} \mathrm{O}$, etc.) and related gases $\left(\mathrm{CO}, \mathrm{NO}_{\mathrm{x}}, \mathrm{SO}_{2}, \mathrm{VOCs}\right.$, etc.) and surface ozone in the atmosphere and ocean, measured under GAW and other programmes, including AGAGE. Remote Fourier transform infrared (FTIR) measurements of total column $\mathrm{N}_{2} \mathrm{O}$ are regularly performed within the Network for the Detection of Atmospheric Composition Change (NDACC), e.g. at Jungfraujoch (Switzerland) (Zander et al., 2005). Tropospheric concentrations of nitrous oxide have also been measured and annual and seasonal variations have been analyzed from observations of the National Oceanic and Atmospheric Administration (NOAA) polar meteorological satellite series (Chédin et al., 2002). Finally, verticallyresolved profiles of tropospheric $\mathrm{N}_{2} \mathrm{O}$ can also been estimated from nadir-viewing infrared spectrometers (Lubrano et al., 2004) such as the Interferometric Monitoring of Greenhouse Gases (IMG) instrument aboard the Advanced Earth Observing Satellite (ADEOS).

For the present study, we have used the opportunity presented by the 2006 launch of the MetOp-A satellite that contains the Infrared Atmospheric Sounding Interferometer (IASI) which measures many atmospheric constituents such as $\mathrm{H}_{2} \mathrm{O}, \mathrm{O}_{3}, \mathrm{CO}_{2}, \mathrm{~N}_{2} \mathrm{O}, \mathrm{CH}_{4}$, CFCs, $\mathrm{CO}$, etc. We particularly focussed on the March-April-May (MAM) 2008 period by making use of the pre-operational, non-validated total col- umn measurements of $\mathrm{N}_{2} \mathrm{O}$ distributed by the European Organisation for the Exploitation of Meteorological Satellites (EUMETSAT).

The IASI instrument and the selection of measured $\mathrm{N}_{2} \mathrm{O}$ total columns (wavelengths, Jacobian, selection flags and retrieval method) will be presented in Sect. 2, together with the MOCAGE model. Surface $\mathrm{N}_{2} \mathrm{O}$ measurements used to rescale MOCAGE outputs to the MAM 2008 period in order to take into account the positive linear trend in $\mathrm{N}_{2} \mathrm{O}$ will be detailed in Sect. 3. The $\mathrm{N}_{2} \mathrm{O}$ fields measured by IASI and calculated by MOCAGE and the comparisons will then be discussed. Finally, conclusions will be presented in Sect. 4.

\section{Measured and modelled data sets}

\subsection{IASI}

The MetOp-A platform has been launched on 19 October 2006. It carries a set of eight instruments, including the Infrared Atmospheric Sounding Interferometer (IASI), that potentially offer improved remote sensing capabilities for both meteorology and climatology. MetOp-A flies in a sunsynchronous polar orbit at a mean altitude of $\sim 815 \mathrm{~km}$. The orbit is inclined $98.7^{\circ}$ to the Equator and crosses the Equator (descending node) at 09:30 mean local solar time. The time for one orbit is $101 \mathrm{~min}$ with a repeat cycle of 29 days. The expected lifetime is 5 years.

The IASI instrument is a high resolution infrared sounder that has been designed for the measurement of improved meteorological parameters for Numerical Weather Prediction (NWP) and climate models. Among its primary objectives there is the estimation and monitoring of trace gases like ozone, methane and carbon monoxide on a global scale (see e.g. Clerbaux et al., 2007; Phulpin et al., 2007 and http: //smsc.cnes.fr/IASI). IASI is an accurately calibrated Fourier Transform Spectrometer (FTS) whose design is based on a classical Michelson interferometer. IASI covers the spectral range from $3.6 \mu \mathrm{m}\left(2760 \mathrm{~cm}^{-1}\right)$ to $15.5 \mu \mathrm{m}\left(645 \mathrm{~cm}^{-1}\right)$ with a spectral resolution between 0.35 and $0.5 \mathrm{~cm}^{-1}$. To achieve global coverage, the IASI instrument observes the Earth with a cross-track swath angle of $\pm 48.3^{\circ}(\sim 2200 \mathrm{~km})$. The instrument field of view consists of four circular pixels of $0.8^{\circ}$ angular diameter, which corresponds to $12 \mathrm{~km}$ on the Earth at nadir.

Within the spectral domain covered by IASI, a number of atmospheric constituents can be measured including $\mathrm{H}_{2} \mathrm{O}$, $\mathrm{O}_{3}, \mathrm{CO}_{2}, \mathrm{~N}_{2} \mathrm{O}, \mathrm{CH}_{4}$, and $\mathrm{CO}$. IR $\mathrm{N}_{2} \mathrm{O}$ spectral signature can be seen in two IASI spectral regions: $1200-1350 \mathrm{~cm}^{-1}$ $\left(v_{1}\right.$ band centred at $\left.1284.91 \mathrm{~cm}^{-1}\right)$ and $2150-2250 \mathrm{~cm}^{-1}\left(\nu_{3}\right.$ band centred at $\left.2223.76 \mathrm{~cm}^{-1}\right)$. The retrieval algorithm for $\mathrm{N}_{2} \mathrm{O}$ is a feed-forward artificial neural network (ANN) following the design described by Turquety et al. (2004). The spectral samples entering the network basically include 30 $\mathrm{N}_{2} \mathrm{O}$ channels positioned in lines of the $v_{3}$ band between 

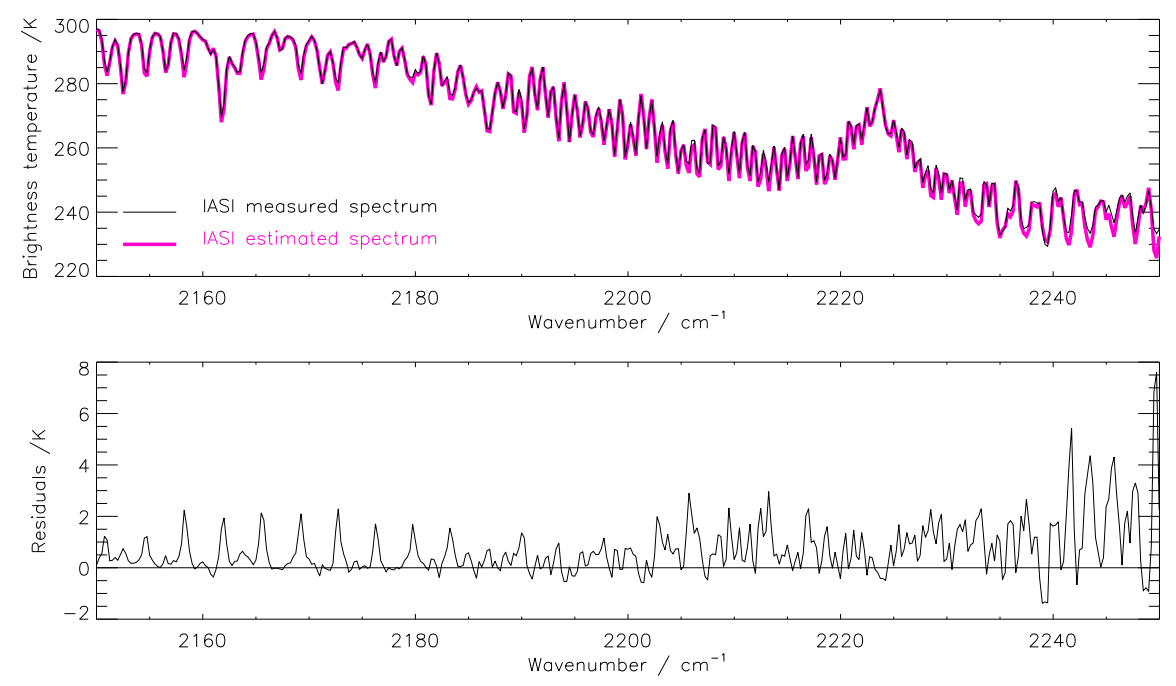

Fig. 1. (Top) Spectra measured by IASI (solid line) over the tropical Pacific Ocean at $\left(158.35^{\circ} \mathrm{E}, 1.41^{\circ} \mathrm{N}\right)$ on $30 \mathrm{December} 2007$ in the $2150-2250 \mathrm{~cm}^{-1}$ region $\left(\mathrm{N}_{2} \mathrm{O} v_{3}\right.$ band) and as estimated by the RTIASI-5.3 forward model using atmospheric composition given by the retrieved state vectors (red line). (Bottom) Residuals, i.e. difference between the measured and the estimated spectra.

2200.75 and $2243.25 \mathrm{~cm}^{-1}$, and three micro-window channels at $2136.25,2142.75$, and $2150.00 \mathrm{~cm}^{-1}$, providing a "baseline" in the water-vapour absorption continuum. Additionally, the inclusion of four lines from the $v_{1}$ band between 1278.75 and $1291.50 \mathrm{~cm}^{-1}$, carefully chosen to avoid the $\mathrm{CH}_{4}$ fundamentals, proved to be advantageous in the training of the network. Surface temperature and a coarse temperature profile, as derived from an Empirical Orthogonal Function (EOF) regression retrieval, enter the network as additional information. The temperature profile is derived assuming a constant $\mathrm{CO}_{2}$ concentration. IASI does not provide true vertical $\mathrm{N}_{2} \mathrm{O}$ columns, as the sensitivity of the measurements is not homogeneous over the vertical profile. Usually, an averaging kernel is applied in the vertical integration of the retrieved profile (e.g. Rodgers and Connor, 2003). Here, the relation between the true vertical columns and the integrated profile applying the averaging kernel is implicit in the retrieval scheme and only represented statistically.

The retrieval method is embedded in the operational IASI Level 2 product processing facility at EUMETSAT (EUMETSAT, 2004; Schlüssel et al., 2005). The estimated accuracy of the $\mathrm{N}_{2} \mathrm{O}$ is about $4 \%$ and the estimated precision is of the order of $20 \%$. As for the accuracy, the value of $4 \%$ refers to the retrieved values from a synthetic data set (spectra calculated via radiative transfer simulations and instrument noise characteristics from assumed atmospheric states) and does not account for errors in the radiative transfer (RT) simulations (e.g. neglecting of Non-Local Thermodynamic Equilibrium (NLTE) effects, errors in spectroscopy, and errors due to truncated RT modelling). The true accuracy cannot be stated without reference to independent means of comparison, which are not available so far. Consequently, in the present study, we consider a random Gaussian error of $\sim 20 \%$ associated to each single pixel of retrieved total column of $\mathrm{N}_{2} \mathrm{O}$ whilst a systematic bias of $4 \%$ cannot be ruled out. Only pixels with a surface pressure greater than $938 \mathrm{hPa}$ are considered in the retrieval process.

An example of a typical IASI spectrum in the 2150$2250 \mathrm{~cm}^{-1}$ spectral region $\left(\mathrm{N}_{2} \mathrm{O}\right.$ band) is shown in Fig. 1 . The spectrum was measured on 31 December 2007 during a daytime overpass over the tropical Pacific Ocean $\left(1.41^{\circ} \mathrm{N}\right.$, $158.35^{\circ} \mathrm{E}$ ) at a viewing angle of $48^{\circ}$. Superimposed on the measured spectrum is the spectrum estimated by the RTIASI5.3 forward model (Matricardi, 2003 and 2004). For the RTIASI-5.3 simulations, we used atmospheric composition state vectors from the ANN $\left(\mathrm{CO}, \mathrm{N}_{2} \mathrm{O}, \mathrm{O}_{3}, \mathrm{CO}_{2}\right.$ and $\left.\mathrm{CH}_{4}\right)$ and from an Empirical Orthogonal Function (EOF) regression and subsequent iterative retrievals (surface temperature, $\mathrm{H}_{2} \mathrm{O}$ and temperature). In the spectral region depicted in Fig. 1, the main absorbers are $\mathrm{CO}, \mathrm{N}_{2} \mathrm{O}$ and $\mathrm{CO}_{2}$. CO predominates between 2150 and $2180 \mathrm{~cm}^{-1}, \mathrm{~N}_{2} \mathrm{O}$ between 2180 and $2240 \mathrm{~cm}^{-1}$ whereas $\mathrm{CO}_{2}$ predominates between 2240 and $2250 \mathrm{~cm}^{-1}$.

For most of the channels with wavenumbers less than $2240 \mathrm{~cm}^{-1}$, the residuals (difference between the measured and estimated spectra) are typically smaller than $2 \mathrm{~K}(0.6 \%)$ suggesting that the atmospheric state vectors retrieved by the ANN have a good accuracy. NLTE effects are not accounted for in the RTIASI-5.3. Although they may have an impact at $2240 \mathrm{~cm}^{-1}$ up to $2250 \mathrm{~cm}^{-1}$ ( $\mathrm{CO}_{2}$ bands) where the residuals reach $\sim 2 \mathrm{~K}$, one should also consider spectroscopic errors and the specification of the temperature and absorber amount profile. This is also true for the spectral regions dominated by the other absorbing species. For instance, in the spectral 

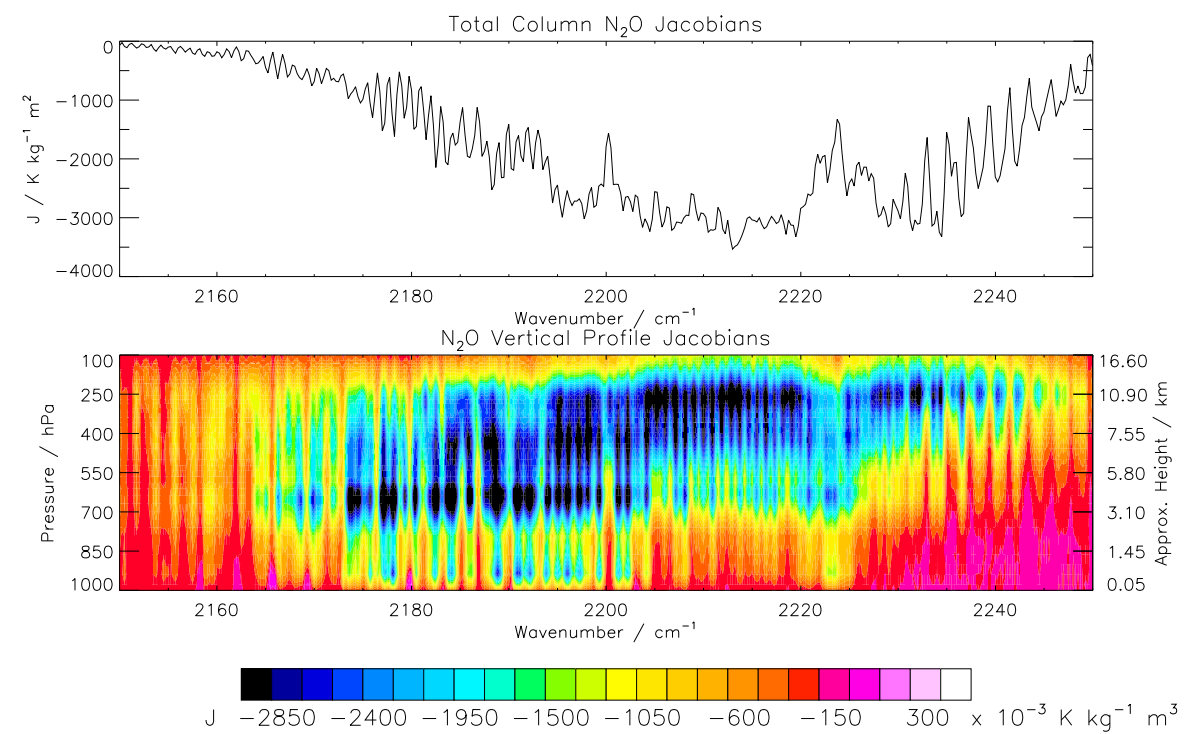

Fig. 2. Jacobians of the total column of $\mathrm{N}_{2} \mathrm{O}$ (top) and of the vertical profiles of $\mathrm{N}_{2} \mathrm{O}$ (bottom), consistent with the estimated spectrum in the $2150-2250 \mathrm{~cm}^{-1}$ region $\left(\mathrm{N}_{2} \mathrm{O} \nu_{3}\right.$ band) shown in Fig. 1. Note that the tropopause pressure is about $93 \mathrm{hPa}(\sim 17 \mathrm{~km})$ at this particular location and time.

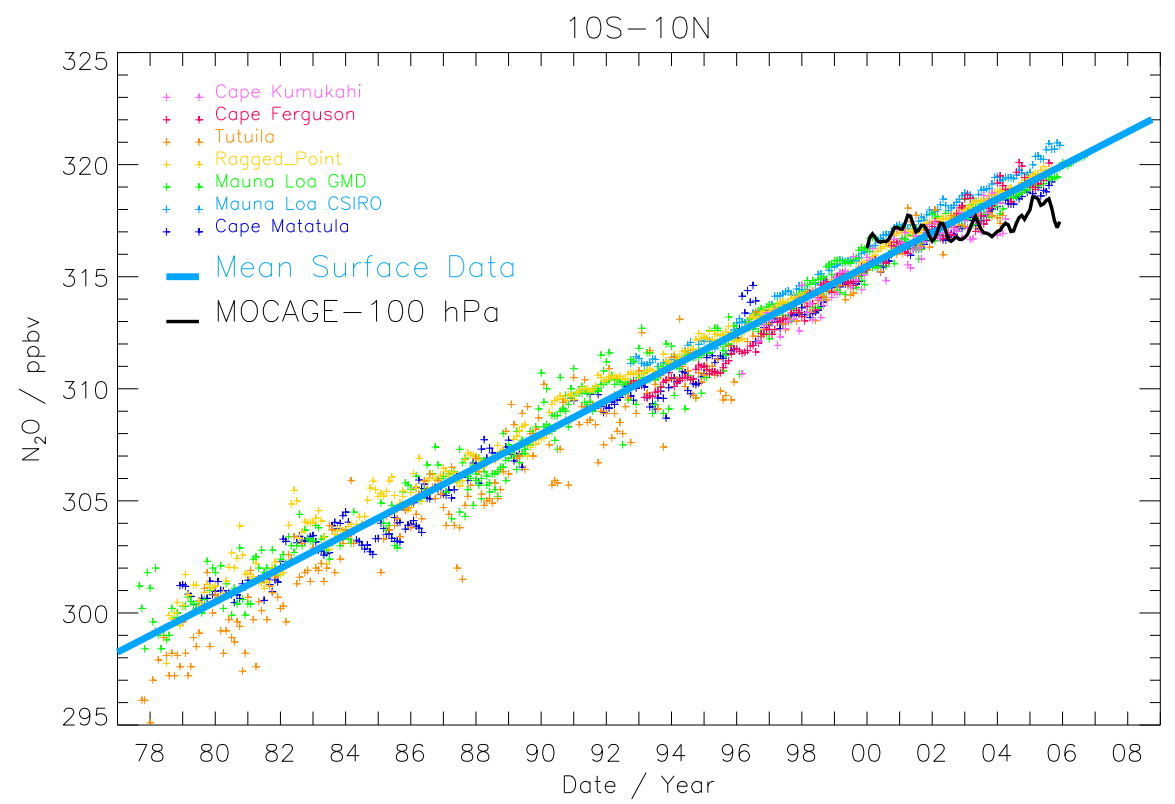

Fig. 3. Time evolution in the $10^{\circ} \mathrm{S}-10^{\circ} \mathrm{N}$ equatorial band of the $\mathrm{N}_{2} \mathrm{O}$ surface data (crosses) from different stations (Cape Kumukahi (pink), Cape Ferguson (red), Tutuila (orange), Ragged Point (yellow), Mauna Loa GMD (green), Mauna Loa CSIRO (light blue) and Cape Matatula (dark blue)) in the $20^{\circ} \mathrm{S}-20^{\circ} \mathrm{N}$ latitudinal band from 1977 to 2007 and its estimated linear trend (thick blue line), and as calculated by MOCAGE at $100 \mathrm{hPa}$ (thick solid line) in 2000-2005.

region dominated by $\mathrm{CO}$ (namely below $2180 \mathrm{~cm}^{-1}$ ), the larger residuals are seen in correspondence of strong $\mathrm{CO}$ lines. Consequently, the residuals could be affected by the specification of the $\mathrm{CO}$ profile and by errors in the specification of the $\mathrm{CO}$ line parameters.
The Jacobians relative to the total columns of $\mathrm{N}_{2} \mathrm{O}$ (quantity actually retrieved by the ANN) and relative to the vertical profile of $\mathrm{N}_{2} \mathrm{O}$ (for information only) are shown in Fig. 2. They basically show the sensitivity of the $\mathrm{N}_{2} \mathrm{O}$ amounts (either total column or vertical profile) to the wavenumbers in 

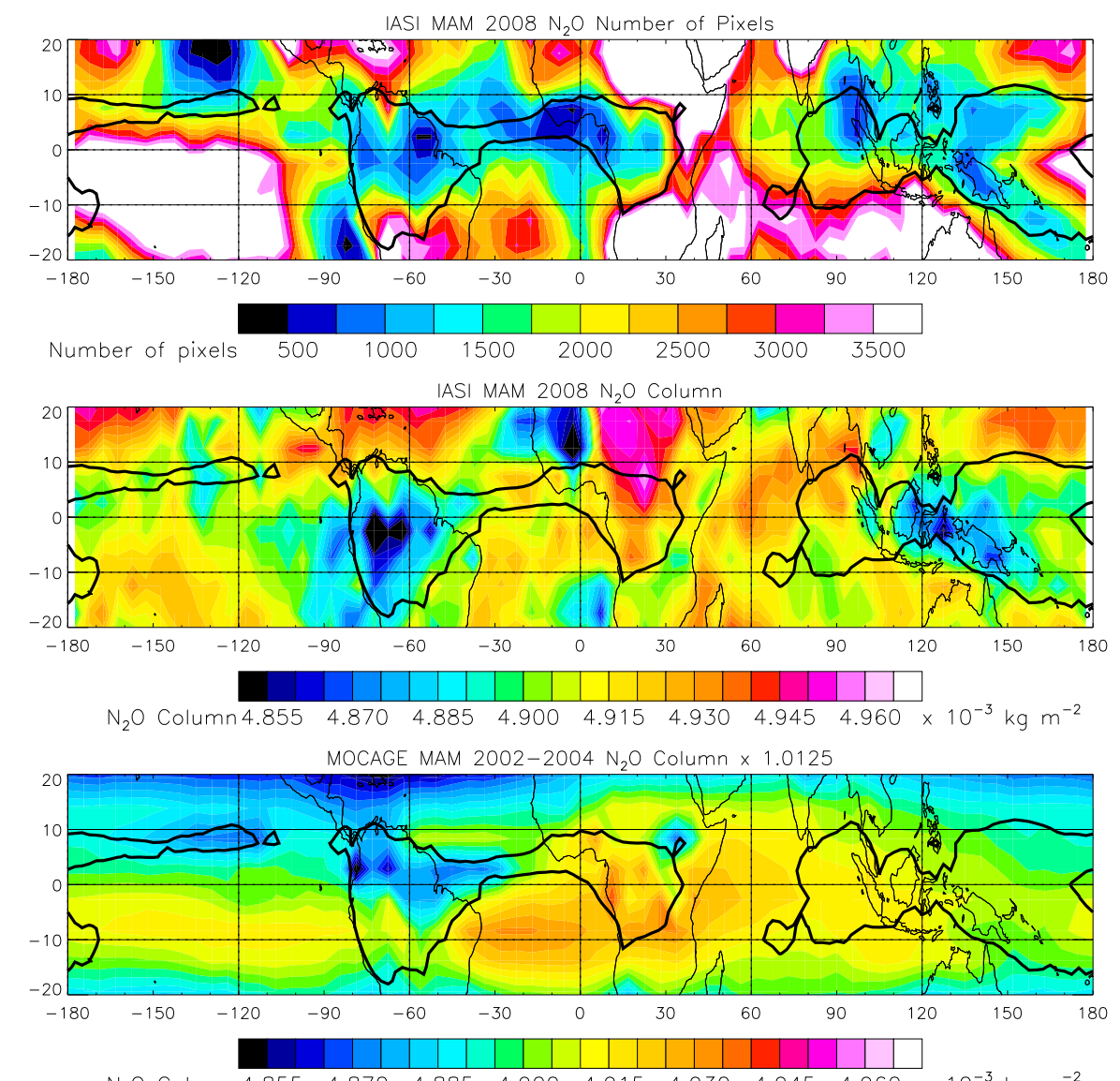

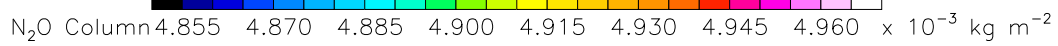
MOCAGE Daily Averaged $\mathrm{N}_{2} \mathrm{O}$ Emissions

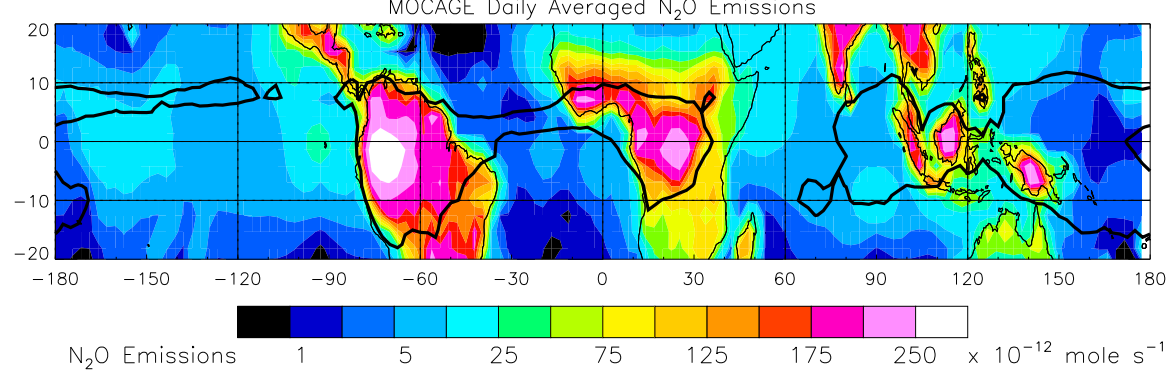

Fig. 4. From top to bottom. Number of total column $\mathrm{N}_{2} \mathrm{O}$ IASI measurement pixels per $5^{\circ} \times 5^{\circ}$ bin used in the present analysis considering the MAM 2008 period. Total column $\mathrm{N}_{2} \mathrm{O}$ fields as measured by IASI in MAM 2008 and as calculated by MOCAGE rescaled by a factor 1.0125 in MAM 2002-2004. MOCAGE daily averaged $\mathrm{N}_{2} \mathrm{O}$ emissions. Superimposed on each figure is the $236 \mathrm{~W} \mathrm{~m}^{-2}$ isocontour (thick solid line) of the OLR from the NOAA/AVHRR in MAM 2002-2004.

the region $2150-2250 \mathrm{~cm}^{-1}$. The maximum of sensitivity in the total column of $\mathrm{N}_{2} \mathrm{O}$ is indeed ranging over 2165$2245 \mathrm{~cm}^{-1}$ peaking in the $2190-2240 \mathrm{~cm}^{-1}$ interval. Considering the vertical distribution of $\mathrm{N}_{2} \mathrm{O}$, the Jacobians are mainly peaking in the $750-200 \mathrm{hPa}$ range (approximately $3-$ $11 \mathrm{~km}$ altitude range) with some sensitivity down to $1000 \mathrm{hPa}$ (around the surface) in the range $2175-2205 \mathrm{~cm}^{-1}$ and up to $100 \mathrm{hPa}(\sim 17 \mathrm{~km})$ in the range $2205-2220 \mathrm{~cm}^{-1}$. Consequently, since $\mathrm{N}_{2} \mathrm{O}$ is well mixed in the troposphere to within
5\% (the mixing ratio is about $320 \mathrm{ppbv}$ in the troposphere and decreases with altitude in the stratosphere), the total column of $\mathrm{N}_{2} \mathrm{O}$ is essentially sensitive to the tropospheric content. In addition, it might also be possible to retrieve verticallyresolved profiles of $\mathrm{N}_{2} \mathrm{O}$ within the entire troposphere.

The $\mathrm{N}_{2} \mathrm{O}$ total columns provided by EUMETSAT for the period from 1 March to 31 May 2008 have been averaged over $5^{\circ} \times 5^{\circ}$ latitude-longitude bins considering only cloudfree data according to cloud flags set in the $\mathrm{L} 2$ product. This 


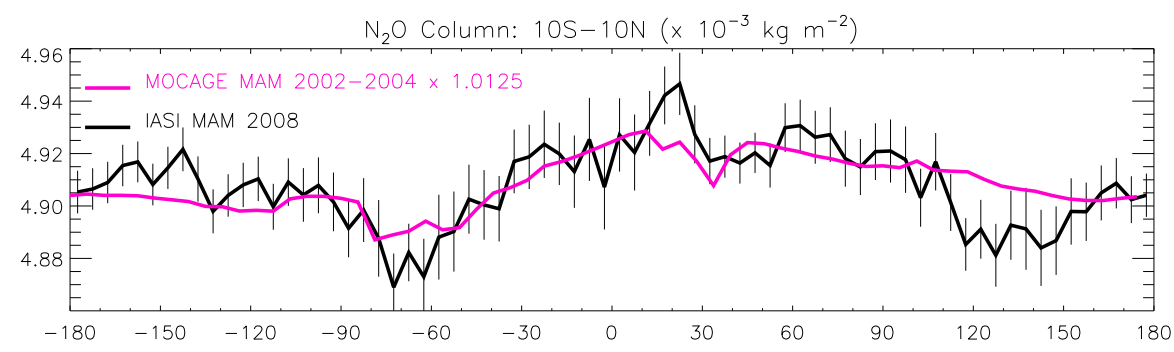

OLR MAM 2002-2004: 10S-10N $\left(\mathrm{W} \mathrm{m} \mathrm{m}^{-2}\right)$
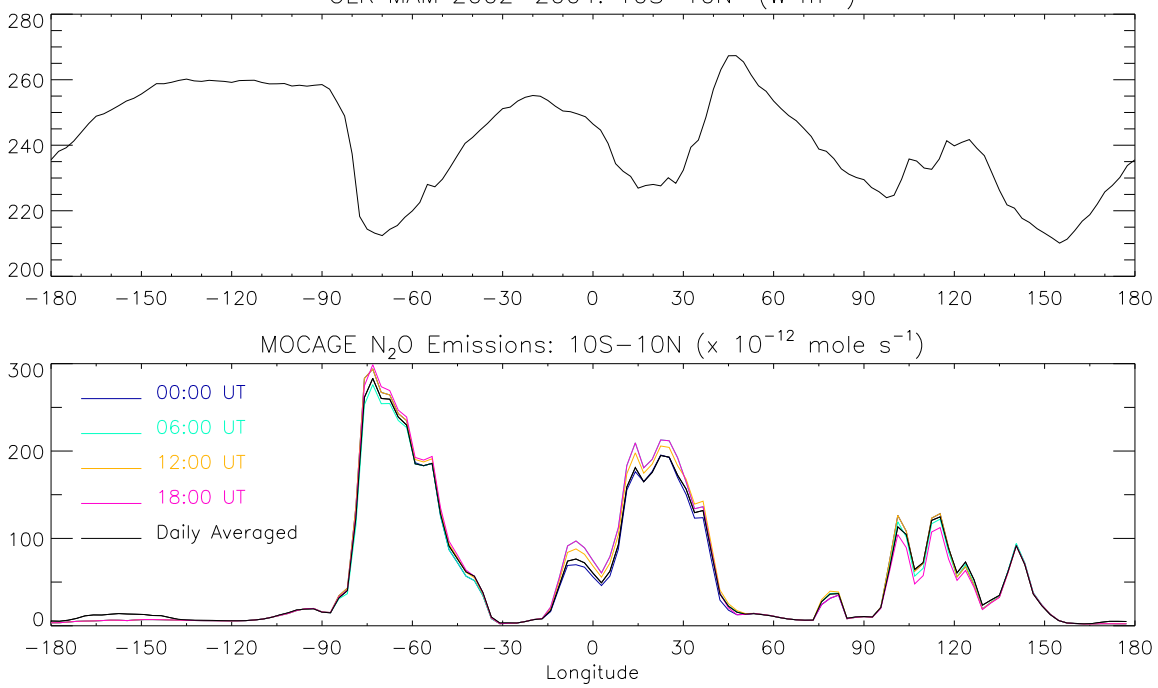

Fig. 5. (Top) Longitudinal distribution of total column $\mathrm{N}_{2} \mathrm{O}$ in the equatorial band $\left(10^{\circ} \mathrm{S}-10^{\circ} \mathrm{N}\right)$ as measured by IASI in MAM 2008 (thick black line), and as calculated by MOCAGE rescaled by a factor 1.0125 in MAM 2002-2004. Vertical bars represent the mean random error on the total column of $\mathrm{N}_{2} \mathrm{O}$ averaged within $10^{\circ} \mathrm{S}-10^{\circ} \mathrm{N}$ and $5^{\circ}$ in longitude considering a $20 \%$ error on a single pixel. (Center) Longitudinal distribution of OLR in MAM 2002-2004 in the equatorial band $\left(10^{\circ} \mathrm{S}-10^{\circ} \mathrm{N}\right)$. (Bottom) Longitudinal distribution of $\mathrm{N}_{2} \mathrm{O}$ emissions used in MOCAGE in the equatorial band $\left(10^{\circ} \mathrm{S}-10^{\circ} \mathrm{N}\right)$ at: 00:00 UT (blue), 06:00 UT (green), 12:00 UT (yellow), 18:00 UT (red), and averaged over $24 \mathrm{~h}$ (black).

corresponds to an average of 500-5000 points per bin in the equatorial band ranging $10^{\circ} \mathrm{S}-10^{\circ} \mathrm{N}$ (see Fig. 4). Note that during the period 16-26 March 2008, no L2 $\mathrm{N}_{2} \mathrm{O}$ data are available. Since in this study we considered a Gaussian distribution of the retrieval random error of $20 \%$ on each individual $\mathrm{N}_{2} \mathrm{O}$ total column, the mean random error associated to the $\mathrm{N}_{2} \mathrm{O}$ total column within one $5^{\circ} \times 5^{\circ}$ bin in the tropics is much better than $1 \%$ over the MAM 2008 period.

\subsection{MOCAGE}

MOCAGE-Climat (Teyssèdre et al., 2007) is the climate version of Météo-France's tropospheric-stratospheric MOCAGE 3-D CTM. The climate version used in this study has 60 layers from the surface up to $0.07 \mathrm{hPa}$, with a horizontal resolution of $5.6^{\circ} \times 5.6^{\circ}$. ECMWF 6-hourly analyses were used to force the model from 1 January 2000 to 31 December 2005. MOCAGE uses a semi-Lagrangian advection scheme and vertical velocities are recalculated from the forcing analyses by solving continuity equation. MOCAGE-
Climat contains a detailed tropospheric-stratospheric chemistry scheme. Initial chemical conditions were taken from a previous simulation to allow the model to quickly reach its numerical equilibrium, especially for long-lived species, such as $\mathrm{N}_{2} \mathrm{O}$. Surface emissions prescribed in MOCAGEClimat are based upon yearly- or monthly-averaged climatologies. The $\mathrm{N}_{2} \mathrm{O}$ surface emissions are taken from the Global Emissions Inventory Activity and are climatologies representative of the year 1990 (Bouwman et al., 1995). They include anthropogenic and biogenic sources, for a total emission rate of $14.7 \mathrm{Tg}(\mathrm{N}) \mathrm{yr}^{-1}$. Note that regarding convection, the present run was performed using the scheme of Betchold et al. (2001). For more information, the reader should consult Ricaud et al. (2007). In the present study, we have considered the March-May 2002-2004 period in order to be consistent with the previous analyses (Ricaud et al., 2007 and 2009). The total column of $\mathrm{N}_{2} \mathrm{O}$ has been calculated considering a surface standard pressure of $1013.25 \mathrm{hPa}$. 

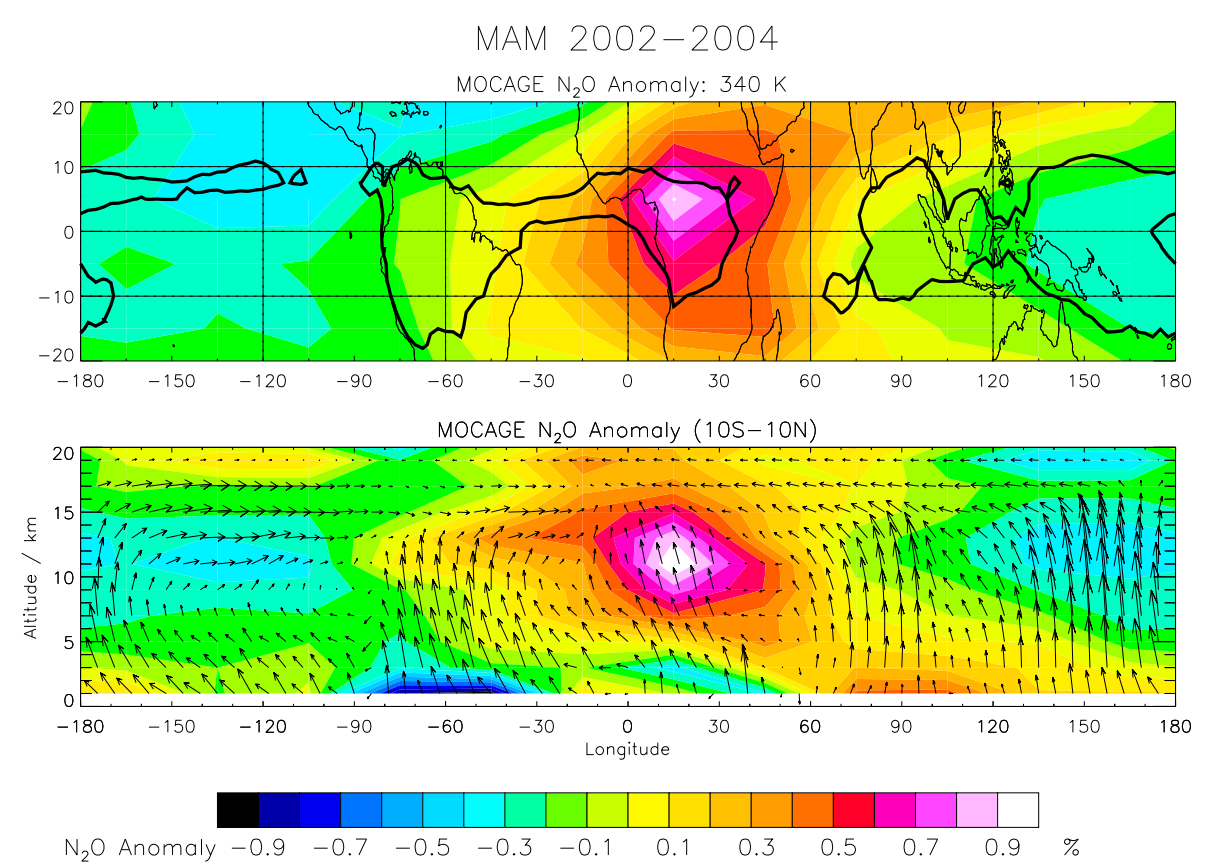

Fig. 6. (Top) $\mathrm{N}_{2} \mathrm{O}$ anomaly (relative difference between $\mathrm{N}_{2} \mathrm{O}$ and its zonal mean, \%) calculated by MOCAGE along the $340-\mathrm{K}$ isentropic surface $(\sim 11 \mathrm{~km})$ in MAM $2002-2004$. Superimposed is the $236 \mathrm{~W} \mathrm{~m}^{-2}$ isocontour (thick solid line) of the OLR from the NOAA/AVHRR in MAM 2002-2004. (Bottom) Altitude-longitude cross-section of $\mathrm{N}_{2} \mathrm{O}$ anomaly calculated by MOCAGE over the period MAM 2002-2004 in the $10^{\circ} \mathrm{S}-10^{\circ} \mathrm{N}$ latitude band. Superimposed are the wind direction and speed where the vertical component is amplified by a factor 100 .

\section{Results and discussion}

\subsection{Surface data}

MOCAGE uses yearly-averaged $\mathrm{N}_{2} \mathrm{O}$ emission inventories. Consequently, except for diurnal variations in the emission rates, there is no monthly variability or trends in the MOCAGE $\mathrm{N}_{2} \mathrm{O}$ data. The 2002-2004 model outputs need to be adjusted towards the 2008 values according to the positive linear trends measured from the ground-based stations located in the tropics and reported in WMO (2006). We have actually used $\mathrm{N}_{2} \mathrm{O}$ measurements from WDCGG stations located within a latitude band wider than $10^{\circ} \mathrm{S}-10^{\circ} \mathrm{N}$, namely $20^{\circ} \mathrm{S}-20^{\circ} \mathrm{N}$, since there are no stations where $\mathrm{N}_{2} \mathrm{O}$ is available within $10^{\circ} \mathrm{S}-10^{\circ} \mathrm{N}$. We have used data for the following sites and time periods: Mauna Loa (USA, $19^{\circ} 32^{\prime} \mathrm{N}$, $\left.155^{\circ} 35^{\prime} \mathrm{W}, 1977-2006\right)$ including two instruments from the Global Monitoring Division (GMD) and the Commonwealth Scientific and Industrial Research Organisation (CSIRO), Cape Kumukahi (USA, $\left.19^{\circ} 31^{\prime} \mathrm{N}, 154^{\circ} 49^{\prime} \mathrm{W}, 1996-2004\right)$, Ragged Point (Barbados, $13^{\circ} 10^{\prime} \mathrm{N}, 59^{\circ} 26^{\prime} \mathrm{W}, 1978-2005$ ), Cape Matatula (USA, $\left.14^{\circ} 15^{\prime} \mathrm{S}, 170^{\circ} 34^{\prime} \mathrm{W}, 1978-2005\right)$, Tutuila (USA, $14^{\circ} 15^{\prime} \mathrm{S}, 170^{\circ} 34^{\prime} \mathrm{W}, 1977-2006$ ), and Cape Ferguson (Australia, $19^{\circ} 17^{\prime} \mathrm{S}, 147^{\circ} 03^{\prime} \mathrm{E}, 1992-2005$ ).

Figure 3 shows the temporal evolution of $\mathrm{N}_{2} \mathrm{O}$ as measured at the surface from the different stations listed above, the linear trends estimated from these ground-based mea- surements from 1977 to 2005 together with the amount of $\mathrm{N}_{2} \mathrm{O}$ as calculated by MOCAGE at $100 \mathrm{hPa}$ over the 2000 2005 period. First of all, an evaluation of the $\mathrm{N}_{2} \mathrm{O}$ linear trend from this surface data set over the period 1977-2005 gives $\sim 0.75 \mathrm{ppbv} \mathrm{yr}^{-1}$. This equatorial rate of change is very consistent with the figures published in WMO (2006) giving $0.74 \pm 0.02 \mathrm{ppbv} \mathrm{yr}^{-1}$ for $1986-2005$. The averaged amount of $\mathrm{N}_{2} \mathrm{O}$ estimated during the 2002-2004 period (namely $\sim 317 \mathrm{ppbv}$ at $100 \mathrm{hPa}$ ) needs to be increased by about $4 \mathrm{ppbv}$ to be consistent with the amount of $\mathrm{N}_{2} \mathrm{O}$ in 2008. Consequently, this corresponds to an increase of $1.25 \%$ over 5 years consistent with the relative trends $\left(0.24 \% \mathrm{yr}^{-1}\right)$ published in WMO (2006). The scaling factor of 1.0125 has thus been applied to the total column of $\mathrm{N}_{2} \mathrm{O}$ calculated by MOCAGE in 2002-2004 in order to be consistent with the total columns of $\mathrm{N}_{2} \mathrm{O}$ in 2008.

\subsection{Equatorial tropospheric $\mathrm{N}_{2} \mathrm{O}$}

The tropical distributions of the total column of $\mathrm{N}_{2} \mathrm{O}$ as measured by IASI in MAM 2008 and as calculated by MOCAGE in MAM 2002-2004 rescaled by a factor 1.0125 are shown in Fig. 4 together with the number of measurement pixels contained in each $5^{\circ} \times 5^{\circ}$ cell. Superimposed is the $236 \mathrm{~W} \mathrm{~m}^{-2}$ isocontour of the Outgoing Longwave Radiation (OLR) from the NOAA/AVHRR corresponding to the MAM 2002-2004 period. As explained in Ricaud et al. (2007), this corresponds to the location of thick clouds, signatures of the 
strong convective systems. They are essentially confined over South America, Central Africa, Indonesia and Western Pacific with a fine tongue between Equator and $10^{\circ} \mathrm{N}$ corresponding to the Inter Tropical Convergence Zone. Within the convective systems, the average number of pixels is ranging 500-1000 whilst outside, the number of pixels is much greater than 2000. This is indeed induced by the presence of clouds within the convection zones limiting the use of cloudfree pixels. Nevertheless, even within convective systems, and considering an individual random error of $20 \%$ on a single pixel, the precision on the total column of $\mathrm{N}_{2} \mathrm{O}$ averaged within $5^{\circ} \times 5^{\circ}$ pixel is much better than $1 \%$.

Considering first the IASI $\mathrm{N}_{2} \mathrm{O}$ distribution, the $\mathrm{N}_{2} \mathrm{O}$ column in the Equatorial band $\left(10^{\circ} \mathrm{S}-10^{\circ} \mathrm{N}\right)$ shows one strong maximum $\left(\sim 4.95 \times 10^{-3} \mathrm{~kg} \mathrm{~m}^{-2}\right)$ over Central Africa and two strong minima over South America $\left(\sim 4.85 \times 10^{-3} \mathrm{~kg} \mathrm{~m}^{-2}\right)$ and Indonesia $\left(\sim 4.87 \times 10^{-3} \mathrm{~kg} \mathrm{~m}^{-2}\right)$. This corresponds to a $\sim 2 \%$ longitudinal variation in the equatorial band. In the extra-equatorial bands $\left(20^{\circ} \mathrm{S}-10^{\circ} \mathrm{S}\right.$ and $\left.10^{\circ} \mathrm{N}-20^{\circ} \mathrm{N}\right)$, the total amounts of IASI $\mathrm{N}_{2} \mathrm{O}$ are on average more intense $\left(4.93-4.96 \times 10^{-3} \mathrm{~kg} \mathrm{~m}^{-2}\right)$ than in the Equatorial band $\left(\sim 4.90 \times 10^{-3} \mathrm{~kg} \mathrm{~m}^{-2}\right)$. If we now consider the $\mathrm{N}_{2} \mathrm{O}$ field as calculated by MOCAGE in the Equatorial band $\left(10^{\circ} \mathrm{S}-10^{\circ} \mathrm{N}\right)$, one can note that there is a broad maximum over the African continent $\left(\sim 4.93 \times 10^{-3} \mathrm{~kg} \mathrm{~m}^{-2}\right)$ that is consistent with IASI and a local maximum over Indonesia $\left(\sim 4.91 \times 10^{-3} \mathrm{~kg} \mathrm{~m}^{-2}\right)$ that is in contradiction with IASI. Over the South American continent, MOCAGE calculates a local minimum in the Northern Hemisphere $\left(\sim 4.86 \times 10^{-3} \mathrm{~kg} \mathrm{~m}^{-2}\right)$ and a local maximum in the Southern Hemisphere $\left(\sim 4.91 \times 10^{-3} \mathrm{~kg} \mathrm{~m}^{-2}\right)$ whilst in IASI there is a strong minimum well confined in the convective area. The longitudinal variation of total column of $\mathrm{N}_{2} \mathrm{O}$ calculated by MOCAGE is weaker $(\sim 1.4 \%)$ than measured by IASI $(\sim 2 \%)$. The greatest discrepancy between IASI and MOCAGE is obviously found in the extra-equatorial band $\left(20^{\circ} \mathrm{S}-10^{\circ} \mathrm{S}\right.$ and $\left.10^{\circ} \mathrm{N}-20^{\circ} \mathrm{N}\right)$. Indeed, MOCAGE systematically shows a net minimum $\left(<4.87 \times 10^{-3} \mathrm{~kg} \mathrm{~m}^{-2}\right)$ in total column of $\mathrm{N}_{2} \mathrm{O}$ poleward to $15^{\circ}$ in both hemispheres whilst in IASI there is a net maximum $\left(>4.93 \times 10^{-3} \mathrm{~kg} \mathrm{~m}^{-2}\right)$.

Outside of the Equatorial belt $\left(10^{\circ} \mathrm{S}-10^{\circ} \mathrm{N}\right)$, some large discrepancies between MOCAGE and IASI $\mathrm{N}_{2} \mathrm{O}$ fields are depicted (e.g. over Sahara) that might be linked to inappropriate surface emissivity values either used in the retrieval process or actually retrieved by the scientific groundsegment. Indeed, the emissivity for that period was underestimated by IASI in desert regions when compared to the emissivity derived from the space-borne Moderate Resolution Imaging Spectroradiometer (MODIS) instrument (Seemann et al., 2008). Within the Equatorial belt, the $\mathrm{N}_{2} \mathrm{O}$ field above Indonesia is more intense in MOCAGE compared to IASI. Indonesia is an active convective region whatever the season considered (warm pool area) but the model has some difficulties to reproduce this phenomenon over that particular area. Indeed, for transport evaluation simulations, MOCAGE does produce a maximum of Radon 222 for instance, in the upper troposphere above America and Africa but a minimum above Indonesia, consistently with other CTM outputs (Jacob et al., 1997; Josse et al., 2004). Another source of discrepancy between IASI and MOCAGE might also be linked to the $\mathrm{N}_{2} \mathrm{O}$ sources used in MOCAGE that could differ significantly from reality, and particularly in the Indonesian sector in 2008. And finally, since averaging kernels are not provided by the ANN, this might also impact on comparisons between measured and modelled total columns of $\mathrm{N}_{2} \mathrm{O}$.

The daily averaged $\mathrm{N}_{2} \mathrm{O}$ emission distribution shows in the equatorial band one intense maximum $\left(>250 \times 10^{-12}\right.$ mole s$\left.^{-1}\right)$ over South America, and two less intense maxima over Central Africa and Indonesia $\left(\sim 175 \times 10^{-12}\right.$ mole s$\left.^{-1}\right)$. The three continental $\mathrm{N}_{2} \mathrm{O}$ maxima are all well confined within deep convective systems. It is particularly interesting to note that despite the fact that the $\mathrm{N}_{2} \mathrm{O}$ emissions are the strongest above South America, the maximum of total column of $\mathrm{N}_{2} \mathrm{O}$ is calculated above Africa with a severe minimum above South America.

Figure 5 shows the longitudinal distributions of $\mathrm{N}_{2} \mathrm{O}$ in the equatorial band $10^{\circ} \mathrm{S}-10^{\circ} \mathrm{N}$ from IASI in MAM 2008 and from MOCAGE in MAM 2002-2004 multiplied by the 1.0125 scale factor, together with the distribution of the OLR and the emissions of $\mathrm{N}_{2} \mathrm{O}$ from MOCAGE in MAM 20022004. The mean random error on the total column of $\mathrm{N}_{2} \mathrm{O}$ averaged within $10^{\circ} \mathrm{S}-10^{\circ} \mathrm{N}$ and $5^{\circ}$ in longitude is ranging from $0.16 \%$ to $0.33 \%$. IASI and rescaled MOCAGE $\mathrm{N}_{2} \mathrm{O}$ do obviously show the same longitudinal distributions with a maximum over Africa $\left(4.93-4.96 \times 10^{-3} \mathrm{~kg} \mathrm{~m}^{-2}\right)$ and a minimum over South America $\left(4.85-4.88 \times 10^{-3} \mathrm{~kg} \mathrm{~m}^{-2}\right)$. The amplitude of the longitudinal variation of total column of $\mathrm{N}_{2} \mathrm{O}$ is $\sim 1.6 \%$ for IASI and $\sim 0.8 \%$ for MOCAGE, namely much greater than the IASI precision of total column $\mathrm{N}_{2} \mathrm{O}$ in each individual $5^{\circ}$ bin within the $10^{\circ} \mathrm{S}-10^{\circ} \mathrm{N}$ equatorial band. There are slight differences between the two data sets with extremes more intense in IASI compared to MOCAGE: one maximum above Africa $\left(4.94 \times 10^{-3} \mathrm{~kg} \mathrm{~m}^{-2}\right.$ for IASI and $4.92 \times 10^{-3} \mathrm{~kg} \mathrm{~m}^{-2}$ for MOCAGE) and one minimum over South America $\left(4.87 \times 10^{-3} \mathrm{~kg} \mathrm{~m}^{-2}\right.$ for IASI and $4.89 \times 10^{-3} \mathrm{~kg} \mathrm{~m}^{-2}$ for MOCAGE). However, the strong minimum above Indonesia $\left(110^{\circ} \mathrm{E}-150^{\circ} \mathrm{E}\right)$ measured by IASI $\left(4.88 \times 10^{-3} \mathrm{~kg} \mathrm{~m}^{-2}\right)$ is not captured by MOCAGE $\left(4.91 \times 10^{-3} \mathrm{~kg} \mathrm{~m}^{-2}\right)$. The diurnal variation of $\mathrm{N}_{2} \mathrm{O}$ emissions is very weak $(<1 \%)$ in MOCAGE with a strong maximum above South America $\left(\sim 300 \times 10^{-12}\right.$ mole s$\left.^{-1}\right)$ and two less intense maxima above Africa $\left(\sim 200 \times 10^{-12}\right.$ mole s $\left.^{-1}\right)$ and Indonesia $\left(\sim 120 \times 10^{-12}\right.$ mole s$\left.^{-1}\right)$, all of them confined in deep convective systems.

The effects of continental convective systems upon the tropospheric $\mathrm{N}_{2} \mathrm{O}$ are different above South America and above Africa. Indeed, although the emission of $\mathrm{N}_{2} \mathrm{O}$ is calculated to be more intense in South America compared to Africa in MAM 2002-2004, the tropospheric amount of $\mathrm{N}_{2} \mathrm{O}$ is more 
intense over Africa than over South America. In fact, the amount of tropospheric $\mathrm{N}_{2} \mathrm{O}$ is calculated and measured to be the greatest above Africa in the equatorial band. Figure 6 shows the anomaly of $\mathrm{N}_{2} \mathrm{O}(\%)$ relative to its equatorial zonal average as calculated by MOCAGE in MAM 20022004 in the tropics at $340-\mathrm{K}$ isentropic level $(\sim 11 \mathrm{~km})$ and along the vertical in the equatorial band $\left(10^{\circ} \mathrm{S}-10^{\circ} \mathrm{N}\right)$. Indeed, the anomaly reaches $\sim 1 \%$ over Central Africa at 340 $\mathrm{K}$ and maximizes $(>0.5 \%)$ between 7 and $15 \mathrm{~km}$ in the middle troposphere.

Furthermore, our results are consistent with the theoretical study by Ricaud et al. (2009) using MOCAGE that shows a net maximum in $\mathrm{N}_{2} \mathrm{O}$ above Africa in the middle troposphere along the $340-\mathrm{K}$ isentropic surface for all seasons. The Walker cells (Fig. 6) are particularly well pronounced: 1) over Pacific (ascending branch over Western Pacific and descending branch westward from the American continent); 2) over Indian Ocean (ascending over Indonesia and descending eastward from the African continent); and, to a lesser extent, 3) over Atlantic Ocean. Consequently, due to the presence of the Hadley cells (ascending branch around the Equator and descending branch in the extra-tropics at $20^{\circ}-30^{\circ}$ latitudes in both hemispheres, see e.g. Barret et al., 2008) and the Walker cells, Africa is a zone of convergence of airmasses coming from different convective regions whilst Western Pacific behaves more like a divergence zone.

\section{Conclusions}

Recent theoretical studies (Ricaud et al., 2007 and 2009) have shown the potentially important effect of Walker and Hadley cells on the tropospheric distribution of $\mathrm{N}_{2} \mathrm{O}$, a longlived species with a lifetime of about 100 years, in the equatorial band $\left(10^{\circ} \mathrm{S}-10^{\circ} \mathrm{N}\right)$, by producing a local maximum above the African continent. In the present study, we are making use of the total columns of $\mathrm{N}_{2} \mathrm{O}$ as measured by the IASI instrument aboard the MetOp-A platform and delivered by EUMETSAT during the March-May 2008 period. Since the total column of $\mathrm{N}_{2} \mathrm{O}$ is essentially weighted to sample the middle troposphere, these cloud-free measurements are used to assess transport processes in the equatorial band $\left(10^{\circ} \mathrm{S}-\right.$ $\left.10^{\circ} \mathrm{N}\right)$. We compared the measured data set with the outputs from the 3-D chemical-transport model MOCAGE during the period MAM 2002-2004 rescaled by a factor 1.0125 in order to represent the positive $\mathrm{N}_{2} \mathrm{O}$ linear trend until MAM 2008. IASI $\mathrm{N}_{2} \mathrm{O}$ equatorial measurements obviously show a maximum over Africa $\left(4.96 \times 10^{-3} \mathrm{~kg} \mathrm{~m}^{-2}\right)$ and a minimum over South America $\left(4.86 \times 10^{-3} \mathrm{~kg} \mathrm{~m}^{-2}\right)$ in reasonable agreement with the outputs from MOCAGE whilst emissions of $\mathrm{N}_{2} \mathrm{O}$ are more intense over America than over Africa. A slight difference between the two data sets is observed above the Western Pacific $\left(110^{\circ} \mathrm{E}-150^{\circ} \mathrm{E}\right)$ with a marked minimum in IASI compared to MOCAGE. The amplitude of the longitudinal variation of total column of $\mathrm{N}_{2} \mathrm{O}$ along the equatorial band is twice as intense in IASI $(\sim 1.6 \%)$ as in MOCAGE $(\sim 0.8 \%)$ data sets, namely much greater than the IASI mean random error on the averaged total column $\mathrm{N}_{2} \mathrm{O}(0.16-0.33 \%)$. Our study is consistent with the fact that Africa is a zone of convergence of airmasses coming from different convective regions whilst Western Pacific behaves more like a divergence zone.

Acknowledgements. IASI has been developed and built under the responsibility of the Centre National d'Etudes Spatiales (CNES, France). It is flown onboard the MetOp satellites as part of the EUMETSAT Polar System. The IASI L2 data are received through the EUMETCast near real time data distribution service. This project has been funded in France by the Centre National de la Recherche Scientifique/Institut National des Sciences de l'Univers (CNRS/INSU) and CNES, by the national programme Les Enveloppes Fluides et Environnement (LEFE) and by the European Commission (EC) through the Network of Excellence ACCENT TROPOSAT 2. IASI total column of nitrous oxide were extracted from the Ether French atmospheric database (http://ether.ipsl.jussieu.fr). Interpolated Outgoing Longwave Radiation data are provided by the NOAA-CIRES ESRL/PSD Climate Diagnostics branch, Boulder, Colorado, USA, from their Web site at http://www.cdc.noaa.gov/. WDCGG data were retrieved from http://gaw.kishou.go.jp/wdcgg/.

\section{Edited by: T. Wagner}

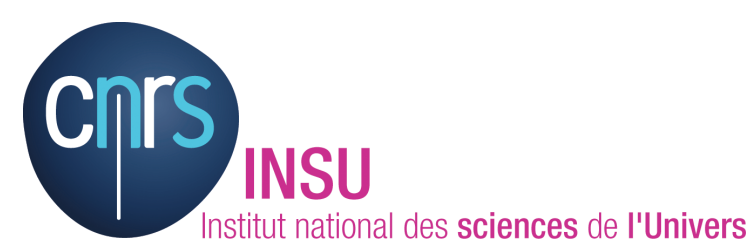

The publication of this article is financed by CNRS-INSU.

\section{References}

Barret, B., Ricaud, P., Mari, C., et al.: Study of the transport pathways of chemical species in the African upper troposphere during the monsoon season based upon the assimilation of spaceborne CO observations in a Chemistry Transport Model, Atmos. Chem. Phys., 8, 3231-3246, 2008,

http://www.atmos-chem-phys.net/8/3231/2008/.

Betchold, P., Bazile, E., Guichard, F., et al.: A mass flux convection scheme for regional and global models, Q. J. Roy. Meteor. Soc., 127, 869-886, 2001.

Bouwman, A. F., Van der Hoek, K. W., and Olivier, J. G. J.: Uncertainties in the global source distribution of nitrous oxide, J. Geophys. Res., 100(D2), 2785-2800, 1995.

Brasseur, G., P., Orlando, J. J., and Tyndall, G. S.: Atmospheric chemistry and global change, 2nd edition, Oxford University Press, New York, Oxford, ISBN-0-19-510521-4, 1999.

Chédin, A., Hollingsworth, A., Scott, N. A., Serrar, S., Crevoisier, C. and Armante, R.: Annual and seasonal variations of atmospheric $\mathrm{CO}_{2}, \mathrm{~N}_{2} \mathrm{O}$ and $\mathrm{CO}$ concentrations retrieved from 
NOAA/TOVS satellite observations, Geophys. Res. Lett., 29(8), 1269, doi:10.1029/2001GL014082, 2002.

Clerbaux, C., Hadji-Lazaro, J., Turquety, S., George, M., Coheur, P.-F., Hurtmans, D., Wespes, C., Herbin, H., Blumstein, D., Tournier, B., and Phulpin, T.: The IASI/MetOp-A I Mission: First observations and highlights of its potential contribution to GMES, COSPAR Inf. Bul., 2007, 19-24, 2007.

EUMETSAT, IASI Level 2 Products Guide, EUM/OPSEPS/MAN/04/0033, available on http://oiswww.eumetsat. org/WEBOPS/eps-pg/IASI-L2/IASIL2-PG-0TOC.htm, 2004.

Jacob, D. J., Prather, M. J., Rasch, P. J., et al.: Evaluation and intercomparison of global atmospheric transport models using $222 \mathrm{Rn}$ and other short-lived tracers, J. Geophys. Res., 102(D5), 59535970, 1997.

Josse, B., Simon, P., and Peuch, V.-H.: Rn-222 global simulations with the multiscale CTM MOCAGE, Tellus, 56B, 339-356, 2004.

Lubrano, A. M., Masiello, G., Matricardi, M., Serio, C., and Cuomo, V.: Retrieving $\mathrm{N}_{2} \mathrm{O}$ from nadir-viewing infrared spectrometers, Tellus, 56B, 249-261, 2004.

Matricardi, M.: RTIASI-4, a new version of the ECMWF fast radiative transfer model for infrared atmospheric sounding interferometer, ECMWF Technical Memorandum No. 425, 63 pp., 2003.

Matricardi, M.: RTIASI-5 user's guide, Report EUMETSAT Contract EUM/CO/02/989/PS, ECMWF, 2004.

Phulpin, T., Blumstein, D., Prel, F., Tournier, B., Prunet, P., and Schlüssel, P.: Applications of IASI on MetOp-A: first results and illustration of potential use for meteorology, climate monitoring, and atmospheric chemistry, Proc. SPIE, 6684, 66840F, doi:10.1117/12.736816, 2007.

Prinn, R. G., Weiss, R. F., Fraser, P. J., Simmonds, P. G., et al.: A history of chemically and radiatively important gases in air deduced from ALE/GAGE/AGAGE, J. Geophys. Res., 105, 17751-17792, 2000.

Ricaud, P., Barret, B., Attié, J.-L., et al.: Impact of land convection on troposphere-stratosphere exchange in the tropics, Atmos. Chem. Phys., 7, 5639-5657, 2007,

http://www.atmos-chem-phys.net/7/5639/2007/.
Ricaud, P., Pommereau, J.-P., Attié, J.-L., Le Flochmoën, E., El Amraoui, L., Teyssèdre, H., Peuch, V.-H., Feng, W., and Chipperfield, M. P.: Equatorial transport as diagnosed from nitrous oxide variability, Atmos. Chem. Phys. Discuss., 9, 4899-4930, 2009, http://www.atmos-chem-phys-discuss.net/9/4899/2009/.

Rodgers, C. D. and Connor, B. J.: Intercomparison of remote sounding instruments, J. Geophysical Res., 108(D3), 4116, doi:10.1029/2002JD002299, 2003.

Schlüssel, P., Hultberg, T. H., Phillips, P. L., August, T., and Calbet, X.: The operational IASI Level 2 Processor, Adv. Space Res., 36, 982-988, 2005.

Seemann, S. W., Borbas, E. E., Knuteson, R. O., Stephenson, G. R., and Huang, H.-L.: Development of a Global Infrared Land Surface Emissivity Database for Application to Clear Sky Sounding Retrievals from Multispectral Satellite Radiance Measurements, J. Appl. Meteorol. Clim., 47, 1, 108-123, doi:10.1175/2007JAMC1590.1, 2008.

Semeniuk, K., McConnell, J. C., Jin, J. J., Jarosz, J. R., Boone, C. D., Bernath, P. F.: $\mathrm{N}_{2} \mathrm{O}$ production by high energy auroral electron precipitation, J. Geophys. Res., 113, D16302, doi:10.1029/2007JD009690, 2008.

Teyssèdre, H., Michou, M., Clark, H. L., et al.: A new tropospheric and stratospheric Chemistry and Transport Model MOCAGEClimat for multi-year studies: evaluation of the present-day climatology and sensitivity to surface processes, Atmos. Chem. Phys., 7, 5815-5860, 2007, http://www.atmos-chem-phys.net/7/5815/2007/.

Turquety, S., Hadji-Lazaro, J., Clerbaux, C., Hauglustaine, D. A., Clough, S. A., Cassé, V., Schlüssel, P., and Mégie, G.: Operational trace gas retrieval algorithm, for the Infrared Atmospheric Sounding Interferometer, J. Geophys. Res., 109, D21301, doi:10.1029/2004JD004821, 2004.

World Meteorological Organization, Scientific assessment of ozone depletion: Rep. 50, Geneva, Switzerland, 2006.

Zander, R., Mahieu, E., Demoulin, P., Duchatelet, P., et al.: Evolution of a dozen non- $\mathrm{CO}_{2}$ greenhouse gases above central Europe since mid-1980s, Environ. Sci., 2(2-3), 295-303, 2005. 